\title{
Comparative Static Analysis of Equilibrium of Supply and Demand in China's Property Markets
}

\author{
Yanshuo Chen \\ Department of Economics, University of Wisconsin-Madison, 53706, US \\ chen527@wisc.edu
}

\begin{abstract}
The property market is a subsystem of the whole society system. Since the 21 st century, China's property market has become increasingly popular and it has created miracles of wealth one after another. Under this trend, a great amount of people flocked to the property sector. At present, under the circumstance of the increase in China's property prices, the study of supply and demand of the property market, as well as its prices, will help practitioners to understand its market discipline and promote stable and healthy development of real estate market. This paper, from the perspective of supply and demand equilibrium theory, analyzes the law of supply and demand of the property market and its relationship with prices. Through the establishment of the model of supply and demand equilibrium in commercial housing, this paper undertakes the Comparative Static Analysis of elasticity of supply and demand and factors influencing housing price.
\end{abstract}

Keywords: The property market; Supply and Demand functions; Equilibrium of Supply and Demand; Comparative Static Analysis.

\section{Introduction}

With the deepening of the reform and the constant improvement of the level of economic development, China's urbanization process is speeding up. A distinctive feature is the residents' housing demand increases, so the property market has gradually developed. The development of the property industry in China is experiencing a tortuous and cyclical road from immature to gradually mature. Since China's reform and opening, the property industry has entered the recovery phase. From 1992 to 1993, there is a nationwide real estate boom. Later, with the implement of tight macroeconomic policy, the real estate industry has entered into the phase of contraction. After subsequent years of digestion and absorption, in 1996, the residential construction became a growth engine. And in 1998, the welfare housing distribution policy was canceled. Such policies marked the development of China's real estate industry has entered a relatively stable period [1].Under the situation that the world economic growth slowed sharply, the rapid development of the real estate industry has undoubtedly played an important role in keeping China's economy growing.

In recent years, the national commercial housing prices continue to rise. So many scholars have explored the influence factors of the rising prices. Some scholars believe that the rise in land prices is the main factors driving prices of real estate [2]. Some scholars also put forward that, system deficiencies such as the imperfection of real estate development mode, as well as the unsound of land management system have led to the high house prices [3].And some other scholars also point out that the growing rigid demand of housing in commercial housing consumption market caused the rise in house prices [4]. Peng and Wheaton (1994) undertakes an econometric analysis on the spillover effects of land supply constraints, using data from 1965 to 1990 in Hong Kong. The empirical results show that the change of land supply has a great influence on the land price, housing price and housing supply [5]. They thought that the undersupply of land lead to the decline in residential supply, combined with consumers' expectation of the future land scarcity and rising rents, eventually result in the increase of the land price and housing price at the same time. C.T.Somerville (1999) points out that the land supply and land management have influence on the development scale [6]. Weston (2002) argues that most existing literature are based on the new classical theory and that is problematic. Through the questionnaire of English major builders, he thought that the prices are the result of builders' individual decisions, which mainly consider the direct costs of land and their competitors [7].These studies, based on several different perspectives, reveal the causes of rising home prices. In this paper, study is given priority to the market equilibrium model of commercial real estate mainly 
consumed by residents and the influence factors of housing prices. Firstly, a commercial housing consumption market supply and demand model will be established, and then endogenous variables and exogenous variables influencing the supply and demand will be analyzed. To sum up, the paper will put forward reasonable suggestions on these influencing factors.

\section{Theoretical model}

\subsection{The demand of the real estate market}

From a microeconomic perspective, demand of real estate refers to the amount of real estate goods which the real estate consumer (in this research mainly refers to the individual consumer), in a specific period of time and at a certain price level, are willing to buy and able to buy. This research mainly considers residents' consumer demand. However, given the truth that real estate is also an effective means for value guarantee and investment, the behavior of citizens buying real estate implies a certain investment demand, so there are some residents demand are either a long-term investment (purchase long-term rental, and then waiting for prices to resell), or short-term speculation (after buying period room, and then sell in a relatively short time to gain profit). And this part of the investment demand temporarily not as the account of this study.

This paper assumes that in the real estate demand model, the main purpose of consuming commodity house is for living, and the main value of the commodity house is provide a certain amount of living space for homeowners. Moreover, this paper assumes that commercial housing market is a perfectly competitive market and the demand of commodity house is depend on the real estate prices and some social economic factors influencing the demand, as illustrate in the linear equation (1). $P$ represents the price, $-b$ represents the price elasticity of real estate demand market. Prices and demand are inversely proportional, so $b>0$. Moreover, income levels also have great impact on the demand for real estate, so elasticity of income level $(y)$ on the demand for real estate is $c$. In China, most people buy houses through banks or provident fund to loan, so interest rate of the loan has a certain influence on the demand for real estate. Hence, the paper uses $r$ to represent the loan interest rate, $-d$ represents elasticity of interest rates for loan on the demand for real estate.

$$
Q^{D}=a-b p+c y-d r
$$

$Q^{D}$ Represents market demand, and a, b, c, d >0.

\subsection{The supply of the real estate market}

The housing supply is another important factor for the real estate market. It depends on the real estate demand, and at the same time, it plays a positive role on promoting the implementation of demand and expand of production. From a microeconomic perspective, the real estate supply refers to the amount of real estate goods which the producers are willing and able to rent and sell in a particular period of time at each price level. Real estate development industry has a large number of enterprises, and it is a market that returns to scale tend to be constant. Commercial housing, as a special commodity, has a long development period, a certain lag on supply. In the short term, the supply of real estate is lack of flexibility, but in long-term, its supply elasticity is larger. Hence, this research mainly consider the long-term supply of real estate. Based on the theory of supply curve, price is the main factors influencing market supply. As price rises, the supply will rise and house price is positive correlation with the supply. Under the analysis of supply market, producers decide whether to product or not according to the discrepancy between price and cost. Therefore, all kinds of building costs (including land costs, financing costs, etc.) is another main factors that influence the supply of real estate market.

This paper assumes that, in a perfect competition market, housing supply is mainly affected by the real estate price, the cost of development. The mathematical models of the housing supply is shown in the linear equation (2). $P$ represents price, $\beta$ represents the price elasticity of real estate market demand, $t$ represents the total cost of development, and $\mu$ represents an elasticity of development cost $(t)$ on the demand for real estate.

$$
\begin{aligned}
& Q^{S}=\alpha+\beta p-\mu t \\
& Q^{S} \text { Represents market supply, and } \alpha, \beta, \quad \mu>0 .
\end{aligned}
$$




\subsection{Market equilibrium and comparative static analysis}

The equilibrium of real estate market happens when market supply is equal to the demand, $Q^{D}=Q^{S}$, which is

$a-b p+c y-d r=\alpha+\beta p-\mu t$

Equilibrium condition gained by equation solving is

$p^{*}=\frac{a+c y-d r-\alpha+\mu t}{\beta+b}$

The supply amount of real estate when market achieves its equilibrium is

$q^{*}=\frac{\alpha b+a \beta}{\beta+b}+\frac{c \beta y-d \beta r-b \mu t}{\beta+b}$

When the real estate market price is below the equilibrium price, under the condition that income level and other factors being equal, the amount of residents who have the purchasing power will increase, so as the demand will increase. However, due to low profits, real estate developers are reluctant to develop more housing, in which tight situation happens. At this point, the market price is bound to rise, and it will continue to rise until the supply and demand are equal, which reaches equilibrium. But in real life, when house prices is above the equilibrium price, it usually not fall to the equilibrium price, and why? In the following part, the relationship between equilibrium quantity and incomes, interest rate, as well as cost and price, will be discussed.

1) The influence of income level $(y)$ on $p^{*}$ and $q^{*}$

According to (4), the paper deduce the function between the residents' income level $y$ and the equilibrium price. Assume that the relation between the two is $\mathrm{f}_{1}$, then $p^{*}=f_{1}(y)$, meet $\frac{\partial p}{\partial y}=\frac{c}{\beta+b}>$ 0 .According to (5), the paper deduce the function between the residents' income level $y$ and equilibrium output $q *$. Assume that the relation between the two is $f_{2}$, then $q *=f 2(y)$, meet $\frac{\partial q}{\partial y}=$ $\frac{c \beta}{\beta+b}>0$. Thus it can be seen that the income level has a positive effect on house prices and equilibrium demand. When the residents' income levels increases, equilibrium price will increase and housing developers are willing to provide more commercial houses. This also explains why prices go up from one hand. Throughout nearly fifteen years of disposable income, disposable income of Chinese residents has substantial jumped to from 6280 yuan in 2000 to 20167 yuan in 2014, which rises as high as about three times driving the growth of the equilibrium price of the house. In addition, for consumers, income is not reversible. Marginal benefit of income increase is far less than the marginal benefit of income decrease. When income increases 1 yuan, the incremental benefits to consumers tend to be small, but when income reduced by 1 yuan, consumers tend to reject.

2) The influence of interest rate $\mathrm{r}$ on $p^{*}$ and $q^{*}$

According to (4), the paper deduce the function between the interest rate $r$ and the equilibrium price. Assume that the relation between the two is $h_{l}$, then $p^{*}=h_{l}(r)$, meet $\frac{\partial p}{\partial r}=\frac{-d}{\beta+b}>0$. According to (5), the paper deduce the function between the interest rate $r$ and equilibrium output $q *$. Assume that the relation between the two is $h_{2}$, then $q^{*}=h 2(r)$, meet $\frac{\partial q}{\partial r}=\frac{-d \beta}{\beta+b}>0$. Thus it can be seen that the interest rate has a negative effect on house prices and equilibrium demand. When the interest rate decreases, equilibrium price will increase and housing developers are willing to provide more commercial houses. When the interest rate decreases, consumers are willing to buy more commercial houses. When the loan interest rate is adjusted, it will produce certain influences on residents buying houses. So countries can also macroscopic control prices by controlling the rates. Throughout nearly ten years of interest rate,

Central bank cut interest rates several times, and loan interest rates continues to decrease. This is also one of the reasons that lead to rising house prices.

3) The influence of developing cost $t$ on $p^{*}$ and $q^{*}$

According to (4), the paper deduce the function between the developing cost $t$ and the equilibrium price. Assume that the relation between the two is $g_{1}$, then $p^{*}=g_{1}(t)$, meet $\frac{\partial p}{\partial t}=\frac{\mu}{\beta+b}>0$.According to 
(5), the paper deduce the function between the developing cost $t$ and equilibrium output $q *$. Assume that the relation between the two is $g_{2}$, then $q *=g 2(t)$, meet $\frac{\partial q}{\partial t}=\frac{-\mu b}{\beta+b} 0$. Thus it can be seen that the developing cost has a positive effect on house prices and equilibrium demand. When the developing cost increases, equilibrium price will increase and housing developers are not willing to provide more commercial houses. If costs increase, the supply price will rise. Without expanding market demand, supply price will not be accepted by the market, so enterprises have to bear increase of cost. Therefore, the understanding which cost determine the price is not comprehensive. Cost constraint of house prices is very weak, and house prices are more determined by the demand.

\section{Conclusion and suggestions}

House prices and the supply of commodity house is related to the livelihood of the people, so the real estate market equilibrium model helps us to gain better understanding the influence factors on the equilibrium price and equilibrium of production for the real estate market. This paper studies the effects of residents' income level, loan interest rates and housing costs on the equilibrium price and equilibrium products using comparative static analysis. As we can be seen from the model analysis, the main factors of house prices rising are the growth of residents' income level, the decrease of loan interest rates, and the increase of demand. Moreover, costs rising also have a certain role in promoting house prices, but it is not the main driving factor of the price of the house.

Curbing rising house prices can be achieved by adjust the credit policy to alter real estate demand structure, such as adjusting lending rates and loan terms to optimize the structure of real estate demand. Housing consumption demand is an important part of Chinese demand, so stimulate the demand for housing can expand domestic demand. But the investment demand of houses should be suppressed by the credit policy, such as raising the loan interest rates on purchasing the second set of housing and adjusting the proportion of pay scale. The government should also strengthen information disclosure and stabilize the market expectations. Real estate supply and demand structure, price changes, the supply of land, the cost of development, the urban planning, other relevant government policies, as well as other kinds of information should be disclosed to the market in time. This is helpful to eliminate the information asymmetry, guide the rational consumption market, and stabilize the market expectations.

\section{References}

[1] Wang Jinming, Gao Tiemei. Dynamic analysis of supply and demand function For China's real estate market [J]. CHINA SOFT SCIENCE, 2004, 04 (04):69-74.

[2] Yan Jinhai. China's house prices and land prices: theory, practice and policy analysis[J], Technical and economical quantitative economic research,2006(1):17-26

[3] Lu Fengling. Contains contradictions and Land Management Mode of real estate price changes [J], Price Theory and Practice, 2005(11):32-33.

[4] Shen Yan. Money supply, inflation, rigid demand pushed up house prices, and then analyze the reason of the rising prices, and the countermeasures and Suggestions [J]. Price Theory and Practice, 2011, 2 (2):31-32.

[5] Peng, R., \& Wheaton, W. C. (1994). Effects of restrictive land supply on housing in Hong Kong: an econometric analysis. Journal of housing research, 5(2), 263.

[6] Somerville, C. T. (1999). Residential construction costs and the supply of new housing: endogeneity and bias in construction cost indexes. The Journal of Real Estate Finance and Economics, 18(1), 43-62.

[7] Weston, R. (2002). The House in the 20th Century. Laurence King, London. 